Jeszcze inne pytania były retoryezne; one ożywiają mowe i czynia ją bardziej bezpośrednią. Polecając np. wielką ufność w modlitwie względem Pana Boga, zwraca się Zbawiciel z takim zapytaniem do Swych słuchaczy: ,Któryż $z$ was, jeśliby go prosil syn jego o chleb, poda mu kamień? Albo jeśli prosi o rybę, poda mu wèja?" (Mt 7, 10).

Chrystus Pan doceniał także w nauczaniu znaczenie częstego powtarzania omówionego już przedmiotu. Często np. uczył o obowiązku i konieczności wiary, pokory, modlitwy i bojaźni przed Bogiem. Wiele też razy powraca do nauki o rzeczach ostatecznych.

Jeszcze godne uwagi w metodzie nauczania Chrystusa sa te cechy, że forme podająca! wykładową, zmieniał na dialogowa, pytająca, i na metodę form połączonych i na odwrót. Nauczał przy tym krótko, prosto i poglądowo, w tonie miłym i pociagającym, w atmosferze radosnego spojrzenia na świat i życie, tak, że nawet nieżyczliwi Mu Nazaretanie „przyświadczali mu i dziwili się wdzięcznym słowom, które wychodziły z ust jego" ( $九 k$ 4, 22). Do natki przygohowy wat sį modlitwą i odbywał ją z świętą powagą, godnością i dokładnością, z poczuciem posłannictwa, po myśli słów Ewangelii: ,Źaden, który rękę swą przykłada do pługa, a ogląda się wstecz, nie jest sposobny do królestwa Bożego" (Łk 9,62).

Kalwaria

Ks. JÓZEF DAJCZAK

\title{
MISTYRA HEBRAJSKA \\ U Św. PAWŁA I W APOKALIPSIE Św. JANA
}

Celem niniejszego, ariykułu jest zwrócenie uwagi na pewien problem, na ogól nieznany, a jednak mający niezmierne znaczenie dla egzegezy Pisma św. Jest ninı starożytna tradycja mistyczna hebrajska.

Dlaczego szukać rozwiązania różnych zagadnień, związanych z egzegeza Nowego Testamentu, w pojęciach mitologiczno-religijnych babilońskich i hellenistycznych, skoro można ju znaleźć jedynie na tym gruncie, na którym księgi Nowego Testamentu powstały, t. zn. w rozległej tradyicji hebrajskiej, a szczególnie w tradycji mistycznej? Nieuwzglednianie tej tradyoji prowadzi do interpretacji całkiem błędnych, do których należy np. interpre- 
tacja pochodzenıa i znaczenia liczb świętych i symbolów w Apokalipsie św. Jana przez (). Allo, O. P., w jego komentarzu do tej kssięgi ${ }^{1}$ ).

Co należy rozumieć przez mistykę hebrajską? O. Lagnange, O. P., w swym dziele "Le judaisme avant Jésus-Christ" ${ }^{2}$ ) stwierdza istnienie u Żydów za czasów Chrystusa pewnego nauczania ezoterycznego, zastrzeżonego dla wtajemniczonych. Mówi o nim Miszna (Chagiga II, 1). Nauczanie to koncentrowało się głównie dokoła dzieła Stworzenia (ma'asêh berêšith) i wizji Ezechiela (merkâbâh). Zajmowali się nim Esseńczycy. O. Laigrange tę tajną naukę określa jako mistykę, wzgl. teologię sekretną. To określenie O. Lagrange'a, w odniesieniu do mistyki hebrajskiej starożytnej jest calkiem słuszne. Ponieważ jednak nauczanie to opieralo się na metodzie symbolicznej, należałoby dodać, że mistyka hebrajska starożytna była to teologia sekretna symboliczna.

Owa tajna nauka hebrajska zawiera lidzne transcendentalne i nadprzyrodzone prawdy, odnoszące się do Boga i Mesjasza, wyrażone symbolicznie. Prawdy te w pojęciu mistyki hebrajskiej są przedmiotem wiary. Nazywa je ona "Tajemnicami wiary" (w Zoharze: rázá dimhêmnûthâ, po hebrajsku: sôd ha'emûnâh, po łacinire: mysterium fidei ${ }^{3}$ ).

Tradycja misiyczna hebrajska nazywa się po hebrajsku: Qabbâlâh. Co znaczy to słowo? Słowo to pochodzi od rdzenia qbl (Piel), ,otrzymywać, odbierać, przyjmowaćc, tzn. pewną naukę, wzgl. prawde. Pojęciem korelatywnym do qabbêl jest słowo mâsar (Qal), „przekazywać“, tzn. pewną prawdę. Te pojęcia korelatywne były dobrze znane św. Pawłowi (I Cor. 11, 23). Rzeczownik zatym Qabbâlâh, pochodzący od czasownika qabbêl, oznacza „tradycje otrzymaną, wzgl. przyjeta" (traditio recepta), tzn. tradycję, otrzymaną əd Mojżesza i proroków, a pochodzącą z objawienia Bożego. Rzeezownik zaś Massôreth (Masora) oznacza „tradycje przekazaną“. Mistycy żydowscy uważają mistyke hehrajską

1) E. B. Allo, L'Apocalypse, Paris, 1921, str. XXXI-XXXVI.

2) M. J. Lagrange, Le judaisme avant Jésus-Christ, Paris, 1931, str. 427-429.

2) Proszę zwrócić uwagę na odmienny sens, jaki to wyrażenie (mysterium fildei) posiada w I Tim. 5, 9, a w formie konsekracji wina we Mszy św. W pierwszym wypadku ma ono sens ogólny, w drugim zaś ma ono sens ściśle zdeterminowany. Podobnież ściśle zdeterminowany sens miewa ono w mistyce hebrajskiej. Wyrażenie to nie znajdıje się $\mathrm{w}$ żadulej $\mathrm{z}$ form konsekracji, przekazanych nam $w$ Ewangeliach $i \mathrm{u}$ św. Pawła. 
Qabbâlâh, za świętą, nazywając ją Qabbâlâh qedoszâh, wzgl. „la santissima Cabala“. Księgę zaś Zohar, która jest głównym kodeksem tej tradycji mistyoznej, nazywają Zôhar haqâdôsz (święty Zohar $)^{4}$ ).

W księgarch Nowego Testamentu znajduje się mnóstwo elementów z literatury talmudycznej i literatury midraszów. Dowodem tego jest pomnikowe dzieło Strack'a i Billerbeck'a: Kommentar zum Neuen Testament aus Talmud und Midrasch" ${ }^{55}$ ). Dlatego nie powinno nas dzi wié twierdzenie nuiektórych autorów, że w księgach Nowego Testamentu znajduje się również mnóstwo elementów mistycznych, albo, jak oni się wyrażają, kabalistycznych. Tak bowiem faktycznie jest. I fakt, że w księgach Nowego Testamentu istnieje wielkie mnóstwo owych pierwiastków mistycznych, jest jednym z dowodów na to, że za czasów Chrystusa Pana i w wieku apostolskim istniala u żydów rozległa tradycja sekretna, zwana „Qabbâlâh qedôszâh", tradycja muistyczna, mająca za cel i przedmiot Boga i Mesjasza. Nie mogła ona nie być znana apostołom. Analiza listu św. Pawla do Żydów i Apokalipsy św. Jana wykazuje, że ci dwaj apostołowie te tradycje znali najlepiej.

Problem tej tradycji mistycznej i jej stosunku do Pisma św. jest bardzo obszenny. Nie można więc w niniejszym artykule poruszyć wszystkich punktów stycznych pomiędzy starożytną mistyką hebrajską a księgami Nowego Testamentu. Wskażę tylko na kilka najbardziej charakterystycznych.

\section{NIEBIESKA JEROZOLIMA I PRZYBYTEK SWIETY.}

Wspólną księgom Nowego Testamentu i mistyce hebrajskiej jest typiczno-analogiczna interpretacja Niebieskiej Jerozolimy i Przybytku świętego z jego sprzętem, personelem i kultem. Według starohebrajskich pojęć mistycznych Przybytek Mojżeszowy ze swoim sprzętem, personelem i kultem jesit symbolem i typem nzeczy nieblieskich, niewidzialnych $\left.{ }^{6}\right)$. To, co jest w niebie, nadzmysto-

4) Księga ta wyszła na światło dzienne w w. XIII. Zawiera jednak niewątpliwie tradycje starożytne. Pierwszy druk: 1558-60.

5) München, 1922-1928.

6) R. Bechai z Saragossy (w. XIII/XIV): Biûr 'al ha-Thôrâh, Wenecja, 1566, fol. 109 b (ad Ex. 25, 9). Zohar, II, fol. 140 b. 
we i niewidzialne, mistyka hebrajska przedstawia sobie w obrazach, wziętych z Przybytku świętego i Swwiątyni. A więc, jak na ziemi istnieje Przybytek święty (później Swiątynia), Przybytek ziemski, tak i w niebie istnieje Przybytek święty, Przybytek niebieski, będący antytypem pierwszego. Kiedyś z „Nową Jerozolima“", zstępująca od Boga z nieba, zstąpi na ziemie i „Przybytek

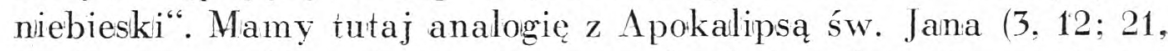
2. 10), z tą tylko odmianą, ze mistyka hebrajska, nie pomijając wcale miasta Jeruzalem, kladzie wiẹkszy nacisk na Przybytek święty $\left.{ }^{\top}\right)$. W Apokalipsie św. Jana mamy aluzję do Przybytku świętego w rozdziale 3,$12 ; 11,19 ; 21,3$.

W Przybytku ziemskim istnieje miejsce najświętsze, ..Swięte Swiętych“; podobnież i w Przybytku niebieskim istnieje: ,Sancta Sanctorum". Na ziemi istnieje Najwyższy Kapłan; podobnież i w niebie istnieje Ancykapłan, którego obrazem i typem jest Arcykaplan ziemslki ${ }^{8}$ ). O Arcykapłanie niebieskim czytamy słowa następujące: "Nikt inny nie może wejść do ,.Swiętego Swiętych" w niebie. jak tỵlko ten, który posiada imię (atrybut) ,Łaska“ (Chesed) ${ }^{9}$ ). On jeden tylko wstępuje do ,.Swiętego Swiętych“, On, który uszczęśliwia Oblubienicę i uświęca najwewnętrzniejszą część ,.Swiętego Swiętych", zwaną Syjonem" ${ }^{10}$ ).

Te same idce mistyczne na temat Przybytku świętego, ziemskiego i niebieskiego, oraz Arcykapłana ziemskiego i niebieskiego wypowiada św. Paweł w liście do Żydów, w rozdziałach 7, 8, 9, 10. Bardzo charakterystyczną myśl wypowiada on w związku z Arcykapłanem niebieskim w 9, 11-12 i 9, 24-28. Arcykapłanem niebieskim, posiadajacym atrybuty Boskie i na tej poidstawie posiadajacym prawo wstępu do niebieskiego Sancta Sanctorum, jest Chrystus, Syn Boży. On właśnie, będąc Boggiem i Człowiekiem,

7) Zohar, Exodus, fol. 108 b; 252 a; 255 a. Jean de Pauly, Sepher haZohar (Le livire de la Splendeur), Paris, 1900-1911, t. III, str. 428; t. IV; str. 254 i 257.

8) Zohar III (Leviticus), fol. 34 a. De Pauly, t. V, str. 90.

9) "Chesed“, Łaska, jest czwartym z rzędu w całym systemie dziesięciu, a pierwszym z rzędu w systemie siedmiu t. z.w. niższych Switateł (Sephîrôth tachtônôth), czyli atrybutów Boskich. W mistyce hebrajskiej starożytnej wszystkie Swiatła (3 wyższe i 7 niższych) utożsamiają się z Bogiem i są nieoddzielne jedno od drugiego.

10) Zohar III (Deuteronomium), Idra zutta. fol. 296 a. De Pauly, t. VI, str. 119. 
wstapił, i to tylko raz jeden, poprzez Przybytek mistyczny, ,nie ręką uczyniony, to jest nie tego stworzenia", do niebieskiego Sancta Sanctorum, prawem własnej krwi, przelanej za grzechy ludzkie, dokonując $\mathrm{w}$ ten sposób odkupienia wiekuistego.

Z niebieskim Przybytkiem świętym łączy się ściśle pojęcie „Oltarza górnego“, wzgl. „Oltarza niebieskiego". Mistyka hebrajska wspomina o "ołtarzu ziemskim“ i jego antytypie, „Ołtarzu górnym, wzgl. niebieskim“, który znajduje się przed „Tronem Majestatu“. To pojęcie „Oltarza niebieskiego" przeziera i w Apokalipsie św. Jana w 6,$9 ; 8,3 ; 9,13 ; 14,18 ; 16,7$ i i. Tak w 8, 3 jest mowa o złotym oltarzu, który znajduje się przed Tronem, a w 9, 13 o ołtarzu, który się znajduje przed obliczem Boga.

Do tego samego zakresu starohebrajskich pojęć mistycznyich, koncentrujących się dokoła Przybytku świętego, należy zapewne także pojęcie „Ołtarza górnego“, „,sublime Altare ante conspectum Divinae Maiestatis" w Kanonie Mszy św. ${ }^{11}$ ).

\section{CZEOWIEK NIEBIESKI (Homo coelestis)}

W I Cor. 15, 47--49 mówi św. Paweł o Człowieku niebieskim. Louis Ginzberg widzi w tym tekście św. Pawła rabinistyczną tradycję o Człowieku niebieskim i twierdzi, na podstawie analizy tego tekstu i porównania z Bereszith Rabbâ VIII 1, że św. Paweł tradycję tę czerpie bezpośrednio z nauki rabinistycznej, a nie z nauki Filona z Aleksandrii ${ }^{12}$ ). Mistyczną tradycję o Człowieku niebieskim w tekście św. Pawła widzi również D. P. L. B. Drach ${ }^{13}$ ).

W mistyce hebrajskiej „Czlowiek niebieski“ nazywa się „Adlam dil'êlâ", „Adalm "illââh", „Adam qadmôn" (Homo primus, antiquus). U Filona nazywa się on ,genikós“, wzgl. epouránios anthropos“. (De allegoriis, I, XII). Przediwieństwem „Człowieka niebieskiego“" jest „człowiek ziemski“, „homo terrestris“" (âdâm dilthattâ).

11) Aniołem 'świętym, który ma Najśw. Ofiarę przenieść przed Tron Majestatu, jest archanioł Gabriel, który w mistyce hebrajskiej pełni rolę pośrednika między Bogiem a ludźmi. str. 18.

12) The Jewish Encyclopaedia, New York, t. I, 1901, art. „Adam Qadmon“"

18) La Cabale des Hébreux, Rome, 1864, str. 70. 
Nauka o „Czlowieku niebieskim“ stanowi jedną z głównych podstaw mistyki hebrajskiej. Początkii tej nauki znajdują się już w najstarszej mistyce hebrajskiej, gdzie termin „Człowiek niebieskii“ ma inne znaczenie, aniżeli w mistyce hebrajskiej późniejszej. W starożytnej mistyce „Człowiek niebieski“ jest to Bóg sam, a ,człowiek ziemski“ jest jego podobieństwem. W „człowieku niebieskim “ łączą się jednak pojęcia Boga i człowieka równocześnie. W Zoharze nazywa się on "Atiqâ d'jômîn". Termin ten wzięty jest z Dan. 7, 9 (Vulgata: „Antiquus dierum“"). U Filona „Człowiek niebieski" ma znaczenie nieco inne. Filon aplikuje poję̨cie „Bóg Człowiek" nie do Boga samego, lecz do pierwszej kreacji Boskkiej, która jesit Bogu prawie równa: jest to ,pierwszy Syn Boży“, medium, $z_{\text {k }}$ którego pomocą świat zosital stworzony $\left.{ }^{14}\right)$.

"Człowiek niebieski“" w myśl Berêszîth Rabbâ (VIII, 1) jest to Mesjasz, którego Duch unosił się nad wodami (Gen. 1, 2), ten sam Duch Boży, o którym mówi Izajasz $(11,2)$. W tradycji rabinistycznej nazywa się on ,pierwszym, a raczej pierwotnym Człowiekiem" (Adam Qadmon), ponieważ istnial przed stworzeniem świata. Św. Paweł nazywa go „druyim Człowiekviem“ (homo secundus, Adlam novissimus), podczas gdy pierwszeigo człowieka na zilemi, Adama, nazywa on ..pierwszym człowiekiem", „homo primus"; (misityka hebrajskka nazywa go âdâm rîschôn w odróżnieniu od âdâm qadmôn), ponieważ pojawil się pierwszy na ziemi. „Człowieka niebieskiego“ zaś nazywa św. Paweł „drugim Człowiekiem“, ponieważ pojawil się na ziemi dopiero później, a także dlatego, że pod względem ciała pochodzi On $z$ połomstwa pierwszego człowieka Adama ${ }^{15}$ ).

Księga Zohar, gdzie „Człowiek niebieski““ jest nazwany także „Zê‘r anpîn“" (Mikroprósopos), charakteryzuje Go, jako istotę, należącą równocześnie do nireba i do ziemi, złożoną z pierwiastlka niebieskiego i ziemskiego, Boskiego i ludzkiego, niematerialnego i materialnego, na wzór człowieka, złożonego z duszy i ciała. Zasiada On, w postaci ,jakoby Człowieka“, na Tronie w wizji Ezechiela (1, 26). Jesit to Czlowiek, który jest syntezą wszystkich Imion Bożych, Człowiek, który zamyka w sobie wszystklie śwliaty nad-

14) S. A. Horodezky, Encyclopaedia Judaica, Berlin, t. I, 1927, art. Adam Qadmon, col. 783-784.

15) L. Ginzberg. The Jewish Encyklopaedia, t. I, art. Adam Qadmon, str. 181. 
ziemskie i ziemskie, Człowiek, który zawiera w sobie wszyștkie tajemnice (râzin), nawêt te, które istniały przed stworzeniem świata $\left.{ }^{16}\right)$.

W ,Siphrâ di-Tz'ni' ûthâ (Liber Mysterii ${ }^{17}$ ) czytamy o „Człowieku niebieskim": , Jest napisano: „Uczyńmy czlowieka...". Nie jest napisano: „Uczyńmy tego człowieka“ (ha-adam) :, lecz: „Uczyńmy człowieka“ (adam), by nie objąć tym określeniem „Człowieka niebieskiego" "âdâm dil'êlâ), który uformowany jest z Imienia pełnego". „Imieniem pełnym" są tutaj cztery litery Imienia Bożego , J H W $\mathrm{H}^{\text {" }}{ }^{18}$ ).

W tejże samej „Księdze Tajemnicy“, w rozdziale 5, znajduje się wariant, w którym jest wzmianka o „Człowieku - Bogu (AdamJehowah), w związku z eksplikacją tekstu. Is. 2, 11: „Et exaltabitur Dominus (Jehowah) solus in die illa“. Czytamy tam: „I gdyby nie ze względu na Człowieka-Boga (Adam-Jehowah), nie ostałby się świat, lecz wszystko zostałoby zniszczone ${ }^{\text {"19}}$ ).

SZABAT NIEBIESKI (sabbatismus). W liście do Żydów $(4,9)$ znajdujemy wyrażenie ,sabbatismus", w tekście greckim: sabbatismós. Prof. Delitzsch w swym hebrajskim przekładzie Nowego Testamentu wyraz ten tłumaczy przez ,m'nûchath szabbâth “ ${ }^{20}$ ). Tłumaczenie hebrajskie anonimowe ma: „szabbathôn“" ${ }^{21}$ ). To słowo u św. Pawła oznacza ów pokój i odpoczynek wiekulisty, którym Bóg ,odpoczywa“ po sześciu dniach stworzenia. Jest to ten sam pokój i odporzmienie Boże, o którym mówi Autor natchniony w Ps. 94, 11: „Non introib́bunt in requiem meam" (sa to słowa Boga, który grozi krnąbrnym i zatwardziałego serca, iż nie wejdą do Odpocznienia Jego). Symbolem i typem tego wiekuistego pokoju jest dzień Szabatu, którego cechą istotną jest oldpoczy wanie po pracach i trudach tygodnia, onaz zatopienie się w Bogu. Sw. Jan czyni aluzję do tego błogosławionego pokoju w Apokalipsie $(14,13)$ : „Beati mortui, qui in Domino moriuntur! Anodo iam, dicit Spiritus, ut requiescant a laboribus suis“" (Ad Hebr. 4, 10: ,...requievit ab operibus

16) Zohar III, Idra rabba, fol. 135 a. De Pauly, t. V, str. 354.

$\left.{ }^{17}\right)$ Ksiegga ta jest najstarsza i najtrudniejszą w Zoharze.

${ }^{18)}$ Zohar II (Exodus), fol. 17? b. De Pauly, t. IV, str. 142.

19) Zohar II, fol. 179 a.

20) B'rith châdâszâh, London, 1937.

$\left.{ }^{21}\right)$ Ha-B'rith ha-châdâszâh al pî ha-Maszîach, London, 1954, Cfr. Is. Salkinson-Chr. D. Ginzburgł B'rith châdâszâh, Wien, 1891. 
suis"). Miejscem wiecznego odpoczynku jest niebo. Ziemia Obiecana, cel i miejsce odpoczynku Izraela po trudach wędrówki synajskiej, jest symbolem i typem krainy niebieskiej i jej wiekuistego pokoju.

Również i w mistyce hebrajskiej starożyinej spoczynek szabatni jest symbolem i typem adpoczynku niebieskiego. Tak np. w Zoharze II, fol. 92 b jest mowa o tym, iż Szabat jest obrazem krainy nieblieskiej, gdzie nie ma zapomnienia, lecz istnieje wiekuista pamięć ${ }^{22}$ ). W tej samej księdze czytamy, iz Ziemia Obiecana symbolizuje krainę niebieską, gdzie ogląda się Majestat Boski ${ }^{23}$ ).

Co więcej, te ideę, według której Szabat jest symbolem odpo‘zynku wiecznego, spotykamy w dzisiejszej hebrajskiej liturgii paschalnej. W .,Seder haggadah szel Pesach“, w związku z ,kielichem błogosławieństwa“" (kôs b’râklıâh) recyłuje się w dzień Szabaltu następująca modlitwe: „Oby Bóg miłosierny pozwolił nam odziedziczyé (zasłużyć sobie na) dzień, który caly jest Szabatem i odpocznieniem w żywocie wiecznym. Oby Bóg miłosierny pozwolił nam odziedziczyé (zasłużyé sobie na) dzień, kłóry jest caly dobry, dzień, który jest caly długi (nieskończony), dzień, w którym sprawiedliwi odpoczywaja ukoronowani i radują się w światłościach Szekiny" ${ }^{24}$ ).

SIEDEM DUCHÓW BOZYYCH (Septem Spiritus Dei). W Apokalipsie św. Jana "Siedmiu Duchów Bożych" nie należy utożsamiać z „siedmiu aniołami“ siedmiu kościolów $(1,20)$ i z , ,siedmiu aniołami", stojaçymi przed obliczem Boga (8, 2). Już Alcazar odróżnlia .,Siedem Duchów Bózych" od ..siedmin aniolów“: „In Apocalypsi Spiritus ab angelis manifeste distinguuntur" ${ }^{* 5}$ ). I rzeczywiście, tak w Apokalipsie św. Jana, jak i w mistyce hebrajskiej „Siedem Duchów Bożych“ odróżnia się od „siedmiu anio-

20) Zohar 11, sithrê Thôrâh, fol. 92 b. De Pauly, t. Ill. str. 596.

2:3) Zohar II. fol. 95 a. De Pauly, i. III, str. 371.

22) London, 1950, str. 40. Prosece zwrócié w tej modlitwie uwage na owe dwa pojęcia ,odpoczynku“ i ,światłości". Te sane dwa pojęcia znajdujemy w IV księdze (Apokalipsie) Ezdrasza, rozdz. 2, 34-55; ,requiem aeternitatis“ i ,lux perpetua". Krytyey tej księgi uwazają te wiersze, jak równiç wstepme rozdzialy, za póńniejszy dodatek, pochodzenia chrześcijańskiego. Lecz czy. zupełnie stusznie?

25i) Lud. ab Alcazar, S. J., Vestigatio arcani sensus in Apocalypsi, Lugduni, 1618, str. 114. 
łów“. „Siedem Duchów Bożych" tak w Apokalipsie św. Jana, jak i w mistyce hebrajskiej jest to jeden Duch Boży siedmioraki, Duch Króla Mesjasza.

W Apokalipsie św. Jana, w rozdz. I - V, mamy trzy święte siódemki, a mianowicie: "Siedem Duchów Bożych" (Septem Spiritus Dei“) (w 1,$4 ; 3,1 ; 4,5 ; 5,6)$, „siedom lamp gorejacych“" (septem lampades ardentes), (w 4, 5) i ...iedem oczu Baranka" (septem oculi), (w 5, 6). W rzeczywistości jest to tylko jedna święta siódemka, ponieważ św. Jan ,siedem lamp gorejących“ i ,siedem oczu Baranka“ utożsamiạ z ..Siedmiu Duchami Bożymi“ (cfr. 4, 5 i 5, 6). Lecz formalnie mamy trzy siódemki. Co do pojeccia , siedmiu oczu“

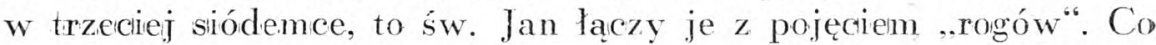
oznacza to ostatnie pojęcie? Lważam, że pojęcie to nie jest pojęciem istotnie odrębnym od pojęcia „sicdmiu oczu“. Jest ono pojęciem pokrewnym i lączy się ściśle z poprzednim. Pojęcia ..siedem oczu“ i „siedem rogów" tworzą jedno pojęcie parzyste, jakkolwiek nire jesit to tautologia.

Co oznacza tutaj róg? Jakkolwiek baranka czy jelenia nie można sobie wyobrazić bez rogów, to w Apoc. 5, 6 św. Jan nie na rogi chciał zwrócić uwagè, lecz na coś innego.

Pojęciu ,róg" odpowiada hebrajski rzeczownik „qeren“, plur. „qarnâjim“. Ale „qeren“ nie tylko oznacza „róg", lecz także „promień słoneczny, wzgl. świetlny $\left.{ }^{26}\right)$. ,Qeren“ może oznaczać także „błysk, polysk, odblask“. Pochodzi bowiem od pierwiastka qrn, który w Ex. 34. 29-30 znaczy „świccić się, blyszczece“. W mistycznym „Midrasz Alpha Belha de-Rabbi Aqiba“" (recenzja A) ezytamy, iż w niebrieskim Gan-Eden „rogi chwaly" (qarnê hôd) zdobia glowy sprawiedliwych. August Winsche w swoim thumaczeniu tego Midraszu, w uwadze do słów ,rogi chwaly" (Hörner der Pracht) wyjaśnia: ,promienie (Strahlen)" ${ }^{2 \tau}$ ). W Apoc. 5, 6 zatem wyrażenie "siedem rogów" może bardzo dobrze oznaczzać promienie wzroku, względnie blask oczu Baranka, tym więcej, gdy uwzględnimy to, że w księdze „Idra rabba“, ,Starzec Najświętszy" ("Atîqûa d'jômîn) blaskiem swoich oczu zapala siedem lamp gorejących. które znajduja się przed Tronem. Uważam zatem, że wyrażenia „siedem rogów" i ,siedem oczu“ Baranka tworzą jedno wyrażenie

${ }^{26}$ ) J. Buxtorf, Lexicon hebraicum et chaldaicum, Glasguae, 1824.

${ }^{27}$ ) A. Jelinek, Beth ha-Midrasch, Leipzig, 1853-1878, tom 1lI, 12-49. August Wünsche, Aus Israels Lelırhallon, t. III. Vide pag. 239. 
parzyste. Wyrażenlia parzyste (zûgê millîm) są ważną cechą literatury biblijnej i kananejskiej ${ }^{24}$ ).

Te same trzy święte siódemki znajdujemy w traktacie „Idrâ rabbâ q'dîszâ". Wszystkie te trzy siódemki skupia w sobie „Starzec Najświętszy" (Antiquus dierum).

.Starzec Najświętszy cosiada ,siedem oczu Jehowy“, o któ rych mówi prorok Zachariasz (3, 9: 4. 10). Lecz ie ...siedem oczu“ Idra Rabba interpretuje jako jedno oko o siedmiu przymiotach. Oko to nazywa sif: 1. oko otwarte, 2. oko wysokie, 3. oko święte, 4. oko Opatrzności, 5. oko. które nie zasypia i nie śpi, 6. oko. które jest strażą wszystkiego, z. oko. które jest ostoją wszystkiego ${ }^{29}$ ).

O Oku tym czyiamy. ze gdyby Oko to zamknęlo się na jedną chwile. nic by się nie ostalo". . Bhogosławiona cząsika tego, na kim Oko to spocznie".

Oko .Starca Najswietszego" posiada ..bialośc “ (blask). która przewyższa wszelką ,białośćc (blask). Blask tego (Oka posiarda trzy odcienie, przy pomocy których Oko to zapala siedem światel Swiecznika niebieskiego (Menorah), znajdujacego się przed Tronem. Te światła Menory niebieskiej nazywają się: Hôd (Chwała), Hâdâr (Majestat). Chedwâh (Radość). Necach (Kwycięstwo). Chesed (Laska), Tiphereth (Piękność); siódma światość, t. zw. Świathość środka. w tym tekście, nie ma specjalnej nazwy $\left.{ }^{30}\right)$. W Apokalipsie, w siedmiorahiej doksologii w 5, 12 i 7. 12. św. Jan zdaje się naśladować nazwy sicdmiu swiatek

Tchnienie .,Starca Najświętszego" jest samym życiem. Od Niego pochodzi Duch żywota, zwany Duchem odpuszczentia grzechów (rûach ha-selîchâh). i Tchnienie (Duch), który ma natchnąć mądrością Syna Dawida. To drugie Tchnienie (Duch) ma spoczać na Królu Mesjaszu, siosownie do słów proroka lzajasza: ..l spocznie na nim Duch Pański... (11, 2)“ Mowa jeest o podwójnỵm Tchnieniu

$\left.{ }^{29}\right)$ U. Cassuto, Biblical Literature and Canaanite Literature, Tarbiz, Jerusalem. vol. XIV, No 1 (October, 1942), 1-10. - - Wyrażenie „Siedem Duchów Bożych i siedem gwiazd" w Apoc. 5, 1 jest wyrażenicm parzystym analogicznym. „Siedem gwiazd“ w mistyce hobrajskiej symbolizuje siedem „Swiateł Bożych“ (S’phîrôth). Owe „siedem gwiazd“ spotykamy już w „Księdze stworzenia" (Sepher Jecirâh).

29) Zohar III, ldra rabba, fol. 150 a (str. 259 wydania wileńskiego z 1882). De Pauly, t. V. str. 340.

3c) Zohar III, Idra rabba, fol 129 bs (str. 258, wydania wileńskiego z 1882). De Pauly, r. V., str. 340. 
ze względu na dwoje nozdrzy, jakie posiada "Starzee Najświętszy“ (symbolizm antropomorficzny). Lecz Tchnienie to jest jedno.

Nastepuje dłuzsza, nieco zawiła, eksplikacja tekstu Is. 11, 2 w związku z Ez. 5z, 9 przez R. Jose'go, który ustala, iz w tekstach tych jest mowa o siedmiu Duchach Bożych: są to sześć Duchów Bożych, wymienionych w tekście lzajasza imiennie, i Duch Boży, wymieniony na czele tekstu. a stojący ponad owymi sześciu i zamykajajcy je w sobie. Jest to jeden Duch, zamykający w sobie wszystkie. Siedem Juchów Bożych w tej eksplikacji odpowiada siedmiu stopniom Tronu Salomona (I Reg. 10, 19). Tron ten w rzeczywistości mial sześć stopni, a według tradycji Mesjasz ma zasiadać ma siedmilu stopmiach. Gidzie więc jest siódmy stopień? R. Jose wyjaśnia: „Sześć stopni jest to sześć Duchów Bożych, wymienionych w Is. 11, 2, a siódmym jest Duch Boży, który jest nad nimi" $\left.{ }^{\prime 31}\right)$.

Widać stąd, że istniala za czasów Chrystusa Pana i w wieku apostolskim u Żydow tradycja o ,,siedmiu Duchach Bożych“, ezyli o siedmiorakim Duchu Bożym, który miał spocząć i zamieszkać w Mesjaszu. Te tradycję znal dobrze św. Jan. Znali ją również bardzo dobrze adresaci Apokalipsy, co wynika stąd, że św. Jan tego pojęcia "Siedmiu Duchów Bożych" w żaden sposób nie wyjaśnia. Autentyczną, bo natchnioną interpretację tej tradycji podaje on nam w rozdz. I-- $T$. Rozumieny także, dlaczego św. Jan sprowarza pojęcic „siedmiu lamp“ i ,siedmiu oczu“ do pojęcia „Siedmiu Duchów Bożych". Owe ,lampy gorejące“, i „oczy" Baranka były tylko symbolem siedmiorakiego Ducha Bożego. Przez nacisk, jaki św. Jan kładzie na .,Siedmiu Duchach Bożych", które posiada Chrystus, jako Syn Czlowieczy-Baranek, chce on podkreślić, iż Chrystus jest obiecanym i oczekiwanym od wieków Synem Dawida, Królem Mesjaszem.

SYSTEM „ŚWIATEŁ“ w Apokalipsie św. Jana. Trzy święte siódemki w Apokalipsie św. Jana: "Siedem Duchów Bożych“", „siedem lamp gorejących“ i ,siedem oczu Baranka“, nie są to sió-

s) Zohar III, Idra rabba, fol. 130 b (str. 260 wydania wileńskiego z 1882). De Pauly, t. V, str. 342-345. - Tę sama tradycję o „Siedmiu Duchach Bozych“, przytacza Gaon R. Eliasz z Wilna w komentarzu do ,.Siphra di Tz'ni'utha“, Wilno-Grodno, 1820, fol. 11 ab. „Siedem Oczu Bożych“ nazywa on ,Siedmiu Oczami Opattrzności: (schebba ênajin d'aschgchûthâ) (fol. 9 b.). 
demiki niczależne. Łączą się one ściśle z liczbą świętą „Trzy“, tworząc w ten sposób świętą liczbę , $10^{\circ}$. Nie należy jednak w tym wy padku pojmować liczby ,.10", jako sumy liczb , $, 3^{\prime \prime} \mathrm{i}, 7^{\circ}$ w sensie matematycznym. To nie jest suma matematyczna. Liczba ,10“ wyraża w tym wypadku tylko ścisły i konieczny wzajemny związek mistyczny pomiędzy liczbami ,,${ }^{*}$ i , , $7^{\prime}$. Te dwie liczby zależa wzajemnie od siebie. Sa to dwie liczby korelatywne. Jedna suponuje drugą. Kwiązek wzajemny tych dwóch liczb świętych jest zaznaczony już przez to, że w rozdz. 1-j mamy trzy święte siódemki (5 razy 7). Charakterystyczne przy tym jest to, że wszystkie trzy sprowadzają się do jednej .,Siedem Duchów Bożych“).

Związek wzajemny tỵch dwóch liczb świętych, 3 i 7 . jest bardzo wyraźny w rozdz. 1, 4. W wierszu tym jest zawarta święta liczba ,"3“, a mianowicie w wyrażeniu: ,Qui est, et qui erat, et qui venturus est". Zwrot ten jest eksplikacją świętego Imienia ., J II W H“, które streśzcza w sobie trzy formy, wzgl. czasy istmienia Boga: ,hôweh w'hâjâh w wihjeh" " ${ }^{32}$ ). Co do trzediego czlonu, to sw. Jan, pisząc: ..et qui venturus est", miał na myśli inne slowo na ,.qui erit“, wzgl. .,futurus“, a mianowicie imiesłów - przymiotnik ,bâ" (jak w'ồîm ha-bâ, saeculum venturum), z sensem zasadniczym „przyjść. I św. Jan, zdaje się. świadomie używa słowa „bâ", żeby przez to napomknąé drugie przyjście Chrystusa. Uważam bowiem, że w. 4 odnosi się do Chrystusa. Twierdzenie to, jak zobaczymy w dalszym toku naszych rozważań, jest w harmonii z systemem dzliesiętnym mistycznym, na którym opiera się symbolizm rozdzialów I-V. Zdania zatem w ww. 4 i 5, są to dwa zdania paralelne. W w. 4 Chrystus. jako Bóg-Mesjasz, jest okréslony w terminach symbolicznych mistycznych (wedtug mistycznego schematu 3 i 7), a w w. 5 jest On określony swym imieniem historyczinym.

:22) R. Bechais z Saragossy, Biur al ha-Torah, Wenecja, 1566, fol. it a, col. b: ad Ex. 3, 14: nazywa te trzy formy imienia Bożego .,sz'lôsch hawâjôth". Lecz ta eksplikacja Imicnia świętego zinajduje się już np. w Targumie Jonatana (w. III/IV): add Dent. 32, 30, i w Szemoth Rabba, par. 3. W tej eksplikacji świętego Imienia ..J H W H“ ma swoje źródło tradycyjna wymowa tegoz Imienia, jako "Jehorwah". Jest to wymowa mistyczna, pierwotnie mniej znana, aniżeli wymowa gramatyczna "Jahweh". W świecie chrześcijańskim jednak tradycyjną wymową była zawsze forma ,.Jehowah", à̇ została wyparta przez wymowę szkolną "Jahweh" (Eichhorn). 
Tę samą eksplikację imienia , J H W H“, co w w. 4, znajdujemy w w. 8. To zdanie odnosi do Chrystusa Ludovicus Alcazar, opierając slę na św. Grzegorzu z Nazjanzu, Rufinie z Aquilei i i. Mówi on: "Assero tamen, in hoc versu sermonem esse de Christo“ “ ${ }^{33}$ ).

Pomijam symboliczno-teologiczne znaldzenie ,trzech egzystencjij" Boskich (sz'lósz hawâjôth), jakie one mają w misityce hebrajskiej $\left.{ }^{34}\right)$. Charakterystyczne $w$ tym wypadku jest to, że święta liczba , 3 " redukuje się do świętej liczby ,1", w której się streszcza i zamyka.

W w. 8, na wstepie, czytamy słowa Chrystusa: „Ego sum Alpha et Omega, Principium ef Finis..." Te same słowa słyszymy w w. 11, w ustach Syna Człow ieczego. Wyrażenia „Alpha et Omega“" i „Principium et Finis“", stojące w paraleli do eksplikacji świętego Imienia , J H W H“", są to trygramy mistyczne.

„Alpha et Omega“" jest transkrypcją grecką hebrajskiego trygramu „Aleph-Taw". Litery ..Aleph-Taw" są skrótem słowa hebrajskiego „Emeth“ (Prawda), które jest synonimem mistycznym imienia Bożego ., J H W H“ ${ }^{35}$ ). ..Emeth“ składa się z trzech liter aleph, mem i taw. ,Aleph jest pierwszą litera hebrajskiego alfabetu. „Mem“ (z uwzględnieniem liter grupy ..Kamnephec)“ jest dokładnie literą śroidkową w alfabecie, a ,Taw" jest literą ostatnią $\left.{ }^{36}\right)$. Te trzy litery słowa ,Emeth" symbolizuja początek, środek i koniec: Principium, Medium, Finis. Wyrazenie zatem „Principium et Finis", będące skrótem ..Principium, Medium, Finis", nie jesit niczym innym, jak eksplikacją wyrażenia "Alpha et Omega". Wyrażenie ..Principium et Finis“" spotykamy już w traktacie „Idra rabba“. Sens, zawarty w tych trygramach, jest ten: Bóg (w Apokalipsie: Chrystus, Syn Boży) jest Porzątkiem, Centrum i Końcem wszysttkiego. Trygram „Alpha et Omega“, oraz jego ekspozyicja, „Principium et Finis" znajdują się w paraleli do trzech "hawâjôth": „hajâh hôweh w"jihjeh": ,.qui erat, et qui est, et qui erit (w Apokalipsie: et qui venturus est). U św. Jana w ekspózycji

૧.) Lud. ab Alcazar, op. लit., str. 129.

32) Interesująca i ważna jest eksplikacja imienia .JHWH“ przez Gaona Eliasza z Wilna (w. 18) w jego komentarzu do „Księgi Tajemunicy“: „Siphrâ di-Tz'nî̀uthâ", Wilno-Grodno, 1820, fol. 2 a.

35) Zohar, fol. 77, col. 307 (Wielki Zohar). Również nr. 3.

3e) Np. R. Bottarello w komentarzu do „Kısięgi Stworzenia“: „Sepher J’tzîrâh“, Mantua, 1662, fol. 28 b. 
świętego Imienia, jest tylko mala, nieistotna zmiana następstwa: „qui est, et qui erat, et qui venturus est".

Innym trygramem, synonimem świętego imienia „. J H W $\mathrm{H}^{6 *}$ jest stowo ..Amen“, skladajace się z liter: aleph, mem it nun ${ }^{37}$ ). W paraleli do zw rotu: Qui est, et qui erat, et qui venturus est, znajduje sie jeszcze zwrot: „Primus et novissimus et vivus" w. 1, 17, 18, jakk równiez: ..Primus et novissimus, qui fuit mortuus et vivit"; (to ostatnie wyrazenie parzyste odpowiada slowu: ,vivus") w 2,8 .

Cóz z tego wynika? Z powyższego wynika, że mamy w obrębie rozdziałów I-V Apokalipsy św. Jana kilka świętych Trójek, które zamyka w sobie Syn Człowieczy-Baranek, oraz że te Trójki znajdlują się w ścislym związku z trzema świętymi Siódemkami, które sprowadzają się do jednego pojęcia „Siedmiu Duchów Bożych“ i które skupia w sobie również Syn Człowieczy-Baranek. Chrystus bowiom jest tym. ..który jest, który byl i który przyjdzie“ $(1,4 ; 1,8)$, równy Temu, który zasiada na Tronie Majestatu $(4,8)$. Chrystus jest Allą i Omegą (1, 8; 1, 11:22, 15), równy pod tym wzzględem Temu. który zasiada na Tronie: $(21,6)$. Chrystus jest „Początkiem i Końcem, pierwszym i ostatnim“ (1, 8. 11. 17: 2, 8; 22, 13). On nazywa sie ..Amen" $(3,14)$. Tenże sam Chrystus, jako Syn Czlowieczy-Baranek, posiarla ., Siedem Duchów Bożych“ (3, 1; 5, 6), stanowiących stygmat Jego godności mesjańskiej. W rozdzialach I-V zatem mamy do czynienia wyraźnie z systemem dzicsiętnym mistycznym, który zamyka w sobrie i streszcza Syn Czlowieczy-Baranek.

System dziesiętmy, rozkładalny na liczby 5 i 7 , jaki odkrywamy w rozdz. I-V Apokalipsy św. Jana, jest systemem mistycznym, stanowiącym podstawe całego systemu liczbowego mistyki hebrajskiej. Jesit to t. zw. system Sw wiateł (S'phîrôth), dzielących się na trzy"Swiatła wyższe (eljônôth) i trzy niższe (tachtônôth). Ten system dziesiętny, rozkładalny na 3 i 7 , znajdujemy juz $w$ ksiegach Mojżesza. Egzegeci-mistycy, R. Bechai z Saragossy ${ }^{{ }^{* 8}}$ ) i R. Menachem Recanati ${ }^{39}$ ) odkrywają system Swiateł w konstrukcji Swiecz-

37) Siphra di-Tz'ni'utha, cap. IJI, dodatek. -- Swięte imię ..J H W H“" ściśle jest to trygram. Jest tetragramem, ponieważ środkowa litera „H“, wystepuje powtórnie na końcu, jako czuarta. To ostatnie „H“" symbolizuje „Boskość ziemska“" (sz'khînthâ diltatthâ) (vide: Gaon Eliasz z Wilna, ut supra).

$\left.{ }^{38}\right)$ R. Bechai b. Ascher, op. cit., fol. 112 a.

${ }^{39}$ ) R. Menachem Recanati, Biur al ha-Torah, Wenecja, 1545, fol. 108 ab. 
nika siedmioramiennego. R. Bechai twierdzi, że system dziesiętny wyraża się zresztą we wszystkich sprzętach Przybytku ${ }^{40}$ ). Na systemie dziesiętnym mistycznym (3 i 7 ) opiera się chrześcijańskokatolicki podział przykazań Dekalogu. R. Recanati dzieli (nie odrzucając $w$ innym micjscu pordziału żydowskiego tradycyjnego) przykazania Dekalogu na 3 pozytywne (.asêh) i 7 negatywnych (ló ta'asêh ${ }^{41}$ ). Mówi on, że dlatego İstnieje dziesięć przykazań, ponieważ istnieje dziesięć „Swiatel" (S"phîrôth).

W mistycè hebrajskiej dziesięć owych Swwiateł skupia i zamyka w sobie "Człowiek niebieski“ (Adam Qadmôn, Adam 'Illââh) $\left.{ }^{42}\right)$. W pierwotnej mistyce Światła te utożsamiają się z istota Boga: Bóg, a owe Swiatia, to jedno.

Idea „Człowieka niebieskiego“", który jest Synem Człowieczym, zasiadającym na Tronie w wizji Fzechiela, przebija w wizji Syna Człowieczego w Apokalipsie św. Jana. Jest On tutaj przedstawiony, jalko należący do nieba i do ziemi, jako Bóg i Człowiek. „Człowiek niebieski" jako pierwszy Człowiek (u św. Pawła jako drugi Człowiek), jest pherwowzorem człowieka-ziemskiego i zasadą całej kreacji Boskiej, bez której to zasady nic istnieć nie może. Mamy aluzję do tej idei w Apoc. 3, 14, gdzie Chrystus jest nazwany: Principiulm creaturae Dei".

WAZZ STARODAWNY (serpens antiquus) i tysiąc lat. Że smok (wąż), o którym mówi św. Jan w Apor. 12, 3 ss., bezpośrednio oznacza konstelację na niebie, jest rzeczą widoczną. Ten obraz gwiezdny u św. Jana symbolizuje Szatana. Skąd św. Jan wziął ten symbol? Czy z mitologii babilońskiej?

*0) Op. cit., fol. 111 a: Kî mispar 'asârâh ráschûm b’khol k'lê ha-mischkân. W „The Jewrish Encyclopaedia“, t. VIII, ma stronie 493, w artykule „Menorah“, podaje nam J. D. Eisenstein iysunek Swiecznika siedmioramiennego $w$ tej formie, $w$ jakiej wyobraża go sohie tradycja rabinistyczna. Swiecznik ten posiada 3 pary ramion, wychodzących z jednego pnia, które razem $z$ pniem podtrzymują 7 lamp. Podstawe Swiecznika tworzy trójkąt równoboczny.

11) Op. cit., fol. 101 a.

$\left.{ }^{42}\right)$ L. Ginzberg, Adam Kadmon, Jewish Encyclopaedia, t. I, str. 185. D. H. Joel, Die Religionsphilosophie des Sohar, Leipzig, 1849, str. 26 z ss. (jakkolwiek pojęcie "Człowieka niebileskiego" thumaczy w duchu mistyki późniejszej). Schemat dzziesięciu Swiateł znajduje się np. w: J. Brierre-Narbonne. Exégèse zoharique des prophéties messianiques, Paris, 1958, wstęp. 
Symbol gwiezdny węża znany jest mistyce hebrajskiej. W najstarszej księdze Zoharu, .,Księdze Tajemnicy“, w rozidz. I i V znajdujemy mistyczną interpretację tekstu Gen. 3, 1 ss. i 3, 15 o wężu kusicielu. Konstelacja na niebie jest właśnie symbolem węża kusiciela. Jest to postać węża długiego, wyciągniętego. w jednym i drugim kierunku. Złośliwym wzrokiem, tuląc ogon do głowy, spogląda on poza siebie (w stronę Niewiasty). Glowa węża-potwora zostaje starta przez, ,wordy Wielkiego Morza“ (majin d“jammâ rabbâ). Wąż ten wykonuje 370 podskoków ponad górami i pagórkami (aluzja do obrotów konstelacji na niebie).

Smok, o którym mówi św. Jan w Apoc. 12. 3ss., nazwany jest w 12. 9 i 20, 2 ,wężem starodawnym“ (serpens antiquus), którym jest diabeł i szatan. W Zoharze wąż kusiciel nazwany jest właśnie „nâchâsz haqaidmôni" (serpens antiquus) ${ }^{43}$ ). Nazywa się on takk̇e „Satan“ i .aniol śmierci" (mal'akh mâweth) Nazywa się także „Sammael“. Jego towarzyszką jest demon żeński ,Lilith “ (od „,lajjil, lajlâh", ,nocc").

Sw. Jan zatem nie potrzebował symbolu smoka-węża brać z mitologii babilońskiej, skoro ten symbol znajduje się w misityce hebrajskiej. Wziąl go on bezpośrednio z tradycji o wężu kusicielu, koncentrujacej się dokoła tekstu Gen. 3, 1 ss. i 3, 15.

W rozidz. 20, 2 ss. mówi św. Jan o związaniu węża na tysiąc lat, o jego zwolnieniu na krótki czals i ponownym związaniu i uwięzieniu na zawsze. W ciągu owego tysiąca lat sprawiedliwi, mający udział .,w pierwszym zmartwychwstaniu“, mają panować razem z Chrystusem.

Uważam. że owo pojęcie ,tysiąca lat", o którym mówi św. Jan, ma związk z ,Księgą Tajemnicy“, rozdz. I, gdzie jest mowa o wężu. Bezpośrednio przed eksplikacją tekstu Gen. 3, 1 jest mowa o sześciu dniach stworzenia i odpowiadającym im sześciu tysiącleciach istniena świata. Na początlku siódmego tysiącletria świat zostanie zniszczony w dwunastu godzinach. Lecz bezpośrednio w nastepnej godzinie Bóg w milosierdziu swoim podniesie świat z ruiny i odnow i go. Następnie tekst, mówiąc o wężu, mówi między innymi, iz wąz ten, z ogonem przytulonym do glowy, spoglądając zlowieszczo poza sicbie, jest ukryty i utajony, lecz ma moc ujawnienia się jednego z tysiąca krótkich dini. Lecz ten teekst jest bardzo niejasny i komentarze do tego tekstu nie są z sobą zgodne.

43) Zohar (Wielki), ed. Sulzbach, 1684, fol. 27, col. 105 ad Gen. 5, 1. 
Komentarz łaciński do tego tekstu w kolekcji Knorr. v. Rosenroth'a wyjaśnia, że w świecie kreacji miarą rachuby są chiliady, oraz że najmniejsze odchylenia w porządku moralnym dają moc wężowi, który wiedy występuje jako oskarżyciel przed Tronem Majestatu ${ }^{44}$ ).

Inny jest komentarz Gaona Eliasza z Wilna. U niego wążpotwór nazywa się „Liwjâthân“ (Lewiatan). Wyrażenie tekstu „eleph jômîn z'êrin“ (tysiąc krótkich dni) tłumaczy on jako „tysiąc lat“" jedną z chiliad świata. Słowa zaś tekstu: ,chad l'eleph jômîn zêrin ithgaliâ" odnosi on do mającego nastąpić w epoce Mesjasza objawienia się „Łaski“ i „Światłości utajonej”“ (ôr gânûz), pozostającej w ukryciu od stworzenia świata. Zniszczenie Lewiatana i zła, oraz objawienie się Łaski i przyjścia Mesjaszia w tej eksplilkacji mieści się w ramach siedmiu chiliad świata. Gdy zostanie zniszczone zlo i objawi się Łaska, spełnią się słowa proroka Izajasza: „Non nocebunt, et non occident... quia repleta est terra scientia Domini, sicut aquae maris operientes" (Is. 11, 9). To objawienie nastąpi w szóstej chiliadzie, z początkiem zaś siódmej nastapi odkuplienie ,małego człowieka“" i przyjdzie Mesjasz ${ }^{45}$ ). Kwestia nie jest bardzo jasna. Charakterystyczną jednak rzecza jest to, że z tradycją „Księgi Tajemnicy“ o wężu łączy się ściśle pojęcie „tysiąca dni (lat)", podobnie jak w Apokalipsie. Objawienie sie „Swiattości utajonej" i Łaski powoduje, rzecz zrozumiała, ubezwładnienie i zwliązanie węża. Kwestia ta wymaga studium.

GEMATRIA. Wyraz ten jest zniekształconą transkrypcją greckiego „grammattia" (nie ,geometria“), od greckiego ,gramma", „litera". Gemaitria jest sztuką wyrażania nazw i imion przy pomocy liczb, które w języku hebrajskim (również i greckim) zasitępowano. z braku znaków specjalnych, literami alfabetu. Analogiczny sposób wyrażania imion osób i rzeczy u starużytnych greków nazywał się „izopsephila“.

Gematria była jedną z metod symbolicznych mistyki hebrajskiej. Tę właśnie metodę stosuje św. Jan w Apolkalipsie, rozdz.

44) Chr. Knorr v. Rosenroth, Kabbala denudata, Sulzbach, 16zz-84, t. II, str. 351. - „Morze Wielkie“, którego wody mają zetrzeć głowę węża, symbolizuje „Mądrość (Chokmah), źródło Jaski i Miłosiendzia. Cfr. Knorr v. Rosenroth, op. cit., t. II, str. 352, oraz Gaon Eliasz z Wilna, op. cit., fol. 20 b.: ,jammâ rabbâ d'Chokh-m'thâ".

45) Gaon Eliasz z Wilna, op. cit., fol. 19 a; 20 a. 
13, 18, żeby wyrazić imię Bestii. Przyznają to niejedni uczeni. Tak np. S. T. Bloomfield powtarza za Heinrichs'em, że miejsce to w Apo. kalipsie $(13,18)$ można zrozumieć w świetle hebrajskiej mistykr i wyjaśnia, że sztuka ta była kiedýs, za czasów Apostola. w wiel. kim poważaniu u Żydów $\left.{ }^{46}\right)$. Ks. A. Gelin nazywa gematrie, którą widzi w Apoc. 13, 18, ,pewnego rodzaju kalkulacją kabalisityczna. dobrze znaną Żydom i Grekom" "'i $)$. P. Vulliaud odkrywa gematrię nie tylko w Apokalipsie, lecz także w Ewangelii św. Jana $\left.{ }^{45}\right)$.

Czy Żydzi zapożyczyli sżuke te, jak i podobne metody mistyczne, od Grekíw? Naleźy sadzić. że sprawa ma się odwrotnie. Grecy naśladowali Żydów. Gematria hebrajska lączy się ściśle z całokształtem hebrajskiej mistyki liczb i liter. łączy się ona z innymi metodami mistycznymi, jak np. z t. zw. zamianą liter (tsêrûph), o której wspomına już najstarsza księga mistyczna hebrajska, „Księga Stwonzenia“ (Sepher j’tzîrâh), a którą według Talmudz. babilonskiego (Berakhoth 55 a) miał wynaleźć Bezaleel, budowniczy Przybytku Mojzeszowego ${ }^{49}$ ). Nigdzie nie spotykamy tak bardzo rozwiniętej mistyki liczb i liter, jak w mistyce hebrajskiej. Co więcej, w religii hebrajskiej spotykamy presupozycję tej mistyki w starożytnych księgach Mojżesza, a mianowicie w symbolice liczbowej świętego Przybytku i świętego imienia „. J H W II“, do której to symboliki mistyka hebrajska nawiązuje i którą wyjaśnią. Bardzo ważną rzeczą jest to, że symbolika liczbowa święiego Przybytku jest przedmiotem specjalnego objawienia Bożego (Ex. 25, 9. 40; 26, 50. Cfr. Act. 7, 44 i Hebr. 8, 5). Ten fakt przemawia bezwzglẹdnie za niezależnością hebrajskiej mistyki od religii i kultów pogańskich.

Co do mistyki liczb u Pitagorasa, to byli autorzy (np. Jan. Reuchlin, Selden, Drach), którzy twierdzili, że Pitagoras swoją wiedzẹ mistyczną zawdziçcza Żydom, a szczególnie prorokowi Ezechielowi: Nazaratus Assyrius, jeden z nauczycieli Pitagorasa,

46) The Greek Testament, London, 1841, ad Apoc. 15, 18: ..This pussage (says Heinrichs) is to be explained from the Cabala of the Jews..."

$\left.{ }^{4}{ }^{4}\right)$ Apocalypse, w kol.: L. Pirot-A. Clamer, La Sainte Bible, t. XII, Paris, 1946, str. 635.

4s) La clé traditionnelle des Evangiles, Paris, 1936.

$\left.{ }^{49}\right)$ Cfr. H. Loewe, Kabbala, w Hastings'a Encyclopaedia of Religions and Ethics, VII, str. 624 . 
to zdaniem niektórych Ojców wlaśnie prorok Ezechiel, wspólczesny - Pitagorasa ${ }^{50}$ ).

$*$

W artykule niniejszym starałem się zwrócić uwagę na kilka punktów stycznych pomiędzy starożytną misityką hebrajską, a księgami Pisma św., szczególnie Nowego Testamentu. Jest praw dą, że o tych meczach się nie mówi i nie pisze. Nie mniej jednak problemy te istniejąa. Posiadają one dla egzegezy Pisma św. znaczenie bardzo wielkie. Sondujemy i szukamy bezcelowo w płytkich wodach hellenizmu i historii porównawczej religii, zamiast azynić poszukiwania w głębokich wodach hebrajskliej mistyki. Przecież ani grecy ani babilończycy nie otrzymali Objawienia Bożego, tylko starożytni hebreowie, naród Boży wybrany: Tam wlaśnie należy nam szukać.

Byli Ojcowie Kościoła, którzy, jak wynika z ich pism, znali mistykę hebrajską, jak św. Klemens Aleksandryjski i św. Epifaniusz. Czy św. Grizegorz W. znał hebrajską tradycję mistyczna? W swej eksplikacji wizji Ezechiela (super Ezechielem Prophetam, hom. 3; cfr. Comm. Evangelistarum) mówi on: „Sancta quatuor animalia..." Dlaczego nazywa on te cztery Istoty ,,sancta animalia“, a nie, jakbyśmy normalnie powiedzieli, ,sacra animalia“. A jednak wyrażenlie ,sancta animalia“ z punktu widzenia teologicznego jest jedynie właściwe, z tym może zastrzeżeniem, że wyraz „,animalia“ lepiej byłoby zastappić wyrazen ,animantia“ (hebr. Chajjôth). Czy św. Grzegorz W. znal mistykę wizji Ezechiela? ${ }^{51}$ ).

Byli w nowszych czasach uczeni chrześcijańscy, między nimi i katolicy, którzy interesowali sie mistyka hebrajską. Wskazywali oni, jakkolwiiek tylko ogólnikowo, na łączność tej mistyki $\mathrm{z}$ Pismem sw. Bylo to w epoce humanizmu i w wiekach następnych, a więc w okresie wielkiego rozkwitu studiów hebraistycz-

$\left.{ }^{50}\right)$ Le Chevalier Drach, De I'harmonie entre l'Eglise et la Synagogue, Paris, 1844, t. I, str. 546 s.

51j Gån R. Eliassz z Wilna wyjaśnia mistykę owych czterech „Chajjôth“ w sposób następujący: „Chajjôth“ Ezechiela, które (jednak) są trzy, a z których każda posiada cztery oblicza a Człowiek obejmuje je wszystkie" (W,'hachajjâh hû "d“" chajjôth schel J'chez'q'êl sche-hên ,g“ w'khol-achath „d“ pânîm w’âdâh kôlêl êth kûllân) (op. cit., fol. 20 b, 21 a). T. zn. Czzłowiek, jedna z czterech „Chajjoth“, obejmuje i zamyka w sobie trzy inne. Tym Czlowiekiem jest „Atîqà d'jômîn“, wzgl. „Czlowiek Niebieski“". 
nych i aramaistycznych. Uczeni ci byli na dobrej drodze do rozwiązania ważnych problemów egzegetycznych.

Tak np., gdy chodzi o Apokalipsę św. Jana, Hugo Grotius đlumaczy dość dobrze, choć jeszcze niezupełnie, pochodzenie wyrażenia ,Alpha et Omega“", jakkolwiek sensu jego nie interpretuje w sposób właściwy ${ }^{52}$ ). O. Ludovicus ab Alcazar, S. J., tłumaczy pojęcie ,.Siedmiu Duchów Bö́ych" w sensie mistyki hebrajskiej, jako atrybuty Boskie, nie zaznaczając jednak, skąd tę interpretację czerpie. Równiez dohrze tlumaczy zwrot: „Qui est, et qui erat, et quil venturus est ${ }^{6{ }^{53}}$ ). O. Athanasius Kircher, S. J. w sensie mistyki hebrajskiej Humaczy Apoc. 1, 4. Apokalipsę św. Jana nazywa on „Apocalypsis Cabbalistica S. Joannis". Mówi on, że do mistyctznej interpretacji Apokalipsy św. Jana najwięcej z wszystkich zbliżył się Cornelius a Lapide w rozdziałach 6, 15, 16 i $20^{54}$ ). Joh. Gottfried Eichhorn widzi elementy mistyczne (kabalistyczne) w Apoc. 1, 4; 13, 18: 19. 12 i, jak mówi, w wielu symbolaća. Mówi on, że budowa Apokalipsy opiera się na t. zw. „Drzewie kabalistycznym" (t. zn. systemie liczbowym dziesiętnym ${ }^{55}$ ). Dr. D. P. L. B. Drach (rabin-konwertyta) odkrywa w Apokalipsie św. Jana „system Światel $\left.{ }^{56}\right)$. Paul Vulliaud mówi, iż konstrukcja Apokalipsy opiera się na procedurze symbolicznej mistycznej (kabalistycznej), i że ta księga przeznaczona była dla wtajemniczonych $\left.{ }^{5 \pi}\right)$.

Bądź co bądź, podobieństwo, wzgl. tożsamość idẹi i symbolów, a nawet stylu, zwrotów i terminów, w mistyce hebrajskiej i w Apokalipsie św. Jana i u św. Pawła jest uderzająca. Kwestia stosunku mistyki hebrajskiej starożytnej do Pisma św. wymaga bezwzględnie poważnego i gruntownego studium.

Paryż

Ks. KEZIMIERZ BOROWICZ

52) Annotationes in Novum Testamentum, pars tertia, Parisiis, 1650, s. 130.

53) Op. cit., pp. 46, 107, 114, 116, 119-122.

54) Cabbala hebraea vetus et christiana, s. 1., 1681, str. 4 i 25

$\left.{ }^{55}\right)$ Einleitung in das Neue Testament, Leipzig, 1804-1810, t. II, str. 347.

58) La Cabale des Hébreux, Rome, 1864, pp. 36 ss.

57) Op. cit., str. 244 . 